\title{
SEBARAN DAERAH SULIT AIR TANAH BERDASARKAN KONDISI GEOLOGI DAERAH PERBUKITAN KECAMATAN PRAMBANAN, SLEMAN, YOGYAKARTA
}

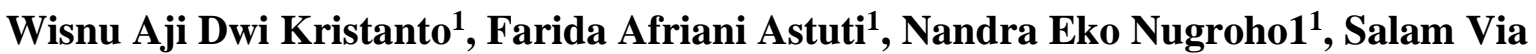 \\ Febriyanti $^{1}$ \\ ${ }^{1)}$ Universitas Pembangunan Nasional Veteran Yogyakarta \\ E-mail: wisnuaji@upnyk.ac.id
}

\begin{abstract}
Abstrak
Ketersediaan air tanah sebagai sumber kebutuhan dasar manusia semakin mengalami degradasi. Hal ini dikarenakan peningkatan jumlah penduduk yang pesat tidak diiringi dengan pemanfaatan air tanah yang baik, sehingga memicu sebaran daerah sulit air tanah. Ketersediaan air tanah dipengaruhi oleh kondisi geologi pada masing-masing daerah. Kondisi geologi berhubungan dengan karakteristik cekungan atau non-cekungan air tanah yang menjadi media penyimpan air tanah. Karakeristik tersebut sangat mempengaruhi porositas dan permeabilitas akuifer air tanah. Sistem hidrogeologi perbukitan Prambanan memiliki karakteristik batuan kelompok non-cekungan dengan kemungkinan kemampuan menyimpan dan meloloskan air kecil. Pada musim hujan umumnya kedalaman air bawah permukaan perbukitan Prambanan melebihi 10 meter dengan fluktuasi berkisar 4-15 meter. Sedangkan pada musim kemarau sebagian besar air bawah permukaan dijumpai pada lapisan akuifer dalam (>40 meter), sehingga menyulitkan penduduk setempat untuk mendayagunakan air bawah permukaan. Berdasarkan gambaran tersebut, menarik dilakukan penelitian sebaran daerah sulit air tanah perbukitan Prambanan. Penelitian menggunakan metode survei dan pemetaan sebaran daerah sulit air tanah. Pemetaan sebaran daerah sulit air tanah meliputi parameter bentuk lahan, ketebalan tanah, satuan batuan, kedalaman muka air tanah, tingkat pelapukan batuan, dan kerapatan bidang diskontinuitas. Enam parameter tersebut dianalisis dengan pembobotan metode analitycal hierarchy process. Hasil analisis pembobotan enam parameter menghasilkan empat zona sulit air di daerah perbukitan Prambanan yaitu sangat sulit, sulit, mudah, dan sangat mudah.
\end{abstract}

Kata Kunci: air tanah, geologi, sebaran daerah sulit air tanah

\begin{abstract}
The availability of groundwater as a source of human basic needs is increasingly experiencing degradation. It is caused by a rapid increase in population that is not followed by good utilization of groundwater, which triggers the groundwater difficult area distribution. The availability of groundwater is influenced by geological conditions in each region. Geological conditions are related to the characteristics of groundwater basins or non-basins wich are groundwater storage media. These characteristics greatly affect the porosity and permeability of groundwater aquifers. The Prambanan hills hydrogeology system has characteristics of non-basin rock groups with the possibility of storing and passing small water. The rainy season generally has the depth of the subsurface water of Prambanan hills beyond 10 meters with fluctuations ranging from 4-15 meters. In dry season, most of the subsurface water found in deep aquifer layers (>40 meters) is making it difficult for local residents to utilize subsurface water. Based on this description, it is interesting to do research on the distribution of hard ground ground areas in the Prambanan hills. The research uses survey methods and mapping of groundwater difficult area distribution. Mapping the distribution of groundwater difficult areas includes parameters of landform, soil thickness, rock units, depth of groundwater surface, rock weathering level, and density of discontinuity fields. The six parameters are analyzed by weighting the analitycal hierarchy process method. The results of the sixparameter weighting analysis resulted in four difficult zones of water in the Prambanan hilly area which are very difficult, difficult, easy, and very easy.
\end{abstract}

Keywords: geology, groundwater, groundwater difficult area distribution

Dikirim/submitted: 19 Desember 2019

Diterima/accepted: 27 Desember 2019 


\section{PENDAHULUAN}

Air merupakan satu dari kebutuhan dasar manusia dan mahluk hidup lainnya untuk hidup. Air dengan kualitas yang paling baik dapat ditemukan di bawah permukaan. Air bawah permukaan terbagi menjadi dua yaitu air tanah dan air bawah tanah. Meresapnya air ke bawah permukaan bumi yaitu melalui sistem air jenuh dan tidak jenuh. Sistem air tanah jenuh adalah air bawah tanah yang terkandung dalam suatu lapisan batuan dan berada pada suatu cekungan air tanah (Sadjab et al., 2012). Dengan kata lain, cekungan air tanah merupakan tempat tersimpannya air tanah (Riastika, 2012). Keberadaan air bawah permukaan dikontrol oleh karakter Cekungan Air Tanah (CAT) dan berkaitan dengan volume air, kecepatan aliran air, dan sebaran air (Hadihardaja, 1997). Cekungan airtanah tersebut umumnya dibatasi oleh batasan yang dikendalikan oleh kondisi hidrogeologi dan geologi atau kondisi hidraulik airtanah, dan umumnya tidak sama dengan batas wilayah pemerintahan (Zeffitni, 2011). Daerah yang memiliki potensi air tanah atau daerah CAT pada umumnya merupakan daerah endapan yang tidak termampatkan, bersifat meloloskan air dan berumur kuarter (Riastika, 2012).

Air tanah tersimpan dalam lapisan pembawa air yang disebut akuifer dan akuifer ini menjadi salah satu faktor penting untuk mengatasi kebutuhan air makhluk hidup (Sulu et al., 2015). Pemanfaatan air tanah oleh penduduk biasanya pada air tanah yang cenderung dangkal karena lebih mudah dalam eksploitasinya. Menurut Jone (2018), perkembangan suatu wilayah dan pembangunan di berbagai sektor juga turut mempengaruhi keberadaan air tanah dan siklus air tanah itu sendiri. Penggunaan air yang tidak sesuai kebutuhan dan pertumbuhan penduduk yang semakin meningkat akan mengakibatkan potensi air tanah semakin berkurang dan berpengaruh pada sebaran daerah sulit air.

Menurut Prayogo (2014), ketersediaan air tanah dipengaruhi oleh kondisi geologi pada masingmasing daerah, yakni litologi, struktur, dan porositas batuan (sistem bukaan). Hasil analisis geologi menunjukkan karakteristik cekungan air tanah atau non-cekungan. Karakeristik tersebut sangat mempengaruhi besar nilai porositas dan permeabilitas batuan penyusun akuifer air tanah.

Ketersediaan air tanah dipengaruhi oleh kondisi geologi pada masing-masing daerah. Kondisi geologi yang berpengaruh yaitu karakteristik cekungan air tanah atau termasuk dalam noncekungan. Karakeristik tersebut sangat mempengaruhi besar nilai porositas dan permeabilitas batuan penyusun akuifer air tanah. 
Sebagian wilayah Kabupaten Sleman memiliki sistem hidrologi yang spesifik yaitu dengan potensi air tanah yang kecil dikarenakan karakteristik batuan yang tidak dapat dengan baik menyimpan dan meneruskan air. Salah satu wilayah dengan karakteristik tersebut adalah daerah perbukitan Prambanan. Morfologi daerah Prambanan berupa perbukitan dengan kondisi litologi daerah Prambanan dan sekitarnya yaitu terbagi menjadi enam satuan batuan yaitu satuan lanau, satuan pasir sedang, satuan pasir halus, satuan tuff, satuan lapilli, dan satuan batupasir dengan tingkat pelapukan yang bervariasi. Keterdapatan struktur geologi pada daerah tersebut berupa kekar, rekahan, dan sesar turun yang membentang dari tenggara ke barat laut dimana struktur tersebut yang membentuk morfologi gawir (Kristanto, 2018).

Sistem hidrogeologi pada daerah perbukitan Prambanan memiliki karakteristik batuan pada kelompok non-cekungan dengan kemungkinan kemampuan menyimpan dan meloloskan air kecil. Menurut data dari Dinas Pekerjaan Umum, Perumahan dan Energi Sumber Daya Mineral (PUP-ESDM DIY) 2018, pada musim hujan umumnya kedalaman air bawah permukaan pada daerah perbukitan Prambanan lebih dari 10 meter dengan fluktuasi kedalaman muka air tanah berkisar antara 4-15 meter. Pada musim kemarau sebagian besar air bawah permukaan dijumpai pada lapisan akuifer yang dalam (> 40 meter) sehingga hal ini menyulitkan penduduk pada wilayah tersebut untuk mendayagunakan air bawah permukaan guna memenuhi kebutuhan air baku. Disamping itu, menurut data BNPB tahun 2010, daerah perbukitan Prambanan termasuk dalam zona kekeringan. Berdasarkan gambaran diatas, daerah perbukitan Prambanan penting dilakukan penelitian sebaran daerah sulit air perbukitan Prambanan, Sleman, Daerah Istimewa Yogyakarta untuk menuai manfaat khususnya bagi penduduk setempat.

\section{METODE PENELITIAN}

Penelitian yang dilakukan merupakan jenis penelitian survei dan pemetaan sebaran daerah sulit air tanah di perbukitan Prambanan. Pengertian survei adalah salah satu teknis riset untuk mengkaji fakta-fakta di lapangan dengan teliti secara deskriptif, berdasarkan pemeriksaan dan pengukuran (Komaruddin, 2000). Peta dasar yang digunakan dalam penelitian ini adalah peta topografi dengan skala 1:25.000 yang diproduksi oleh Bakosurtanal tahun 2018. Keseluruhan tahapan dalam penelitian ini tertuang dengan ringkas dalam diagram alir penelitian pada gambar 1. 


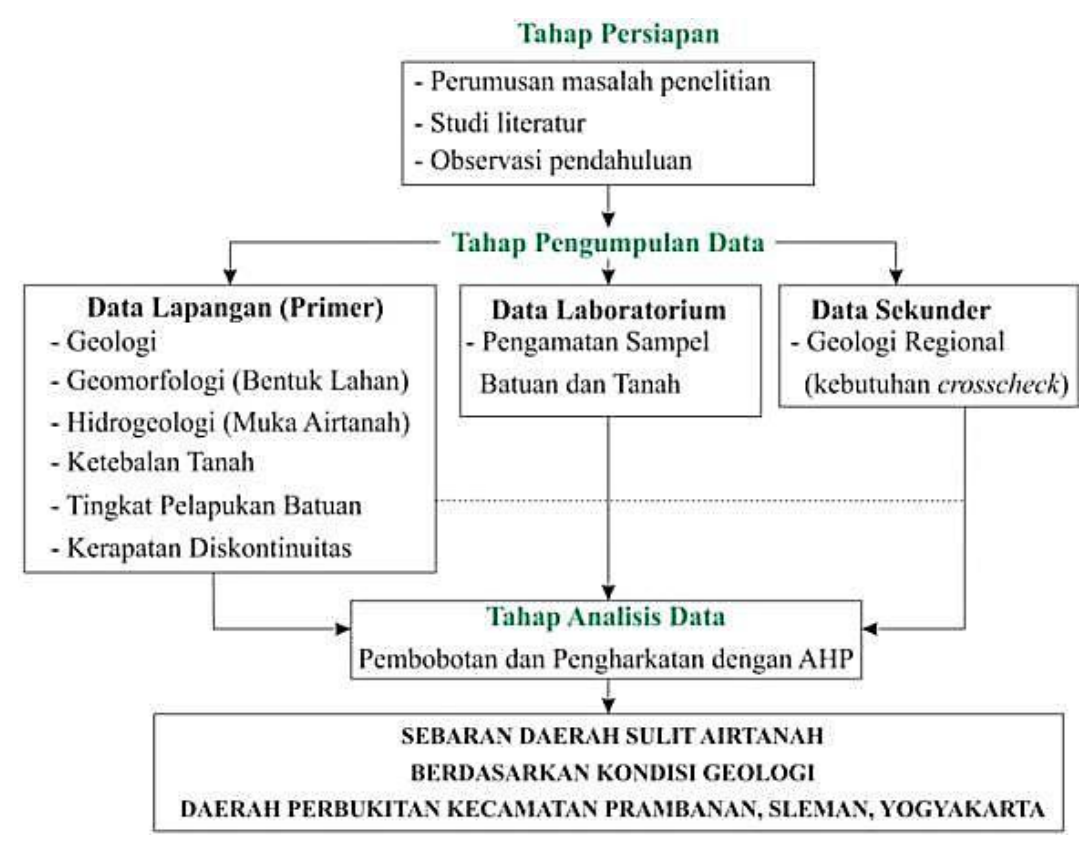

Gambar 1. Diagram alir penelitian

Pemetaan sebaran daerah sulit air tanah meliputi parameter bentuk lahan, ketebalan tanah, satuan batuan, kedalaman muka air tanah, tingkat pelapukan batuan, dan kerapatan bidang diskontinuitas. Adapun setiap parameter tersebut memiliki karakteristik yang saling terkait dan mendukung gambaran keberadaan air tanah pada suatu daerah. Parameter bentuk lahan memberikan gambaran tangkapan air permukaan. Semakin landai tangkapan air semakin baik dikarenakan akan lebih sedikit air yang menjadi runoff. Parameter ketebalan tanah terkait proses terjadinya infiltrasi (Aryanto et al., 2017). Semakin tebal tanah akan semakin banyak air yang terinfiltrasi. Parameter satuan batuan terkait kualitas akuifer yang bertindak sebagai penyimpan dan penyalur air tanah. Setiap batuan akuifer yang ada di tiap satuan batuan memiliki sifat hidrolika porositas dan permeabilitas yang bervariasi (Sunarwan et al., 2015). Kedalaman muka air tanah terkait dengan kemudahan eksploitasi air tanah. Parameter tingkat pelapukan batuan terkait dengan kemampuan infiltrasi dan kualitas akuifer serta hubungan antar sistem akuifer. Parameter kerapatan bidang diskontinuitas terkait dengan kemungkinan sistem akuifer sekunder.

Analisis terhadap keenam parameter yang digunakan pada penelitian ini dilakukan menggunakan pembobotan (weighting) dan pengharkatan (rating) dengan menggunakan metode analitycal hierarchy process (AHP) yang dikemukakan oleh Saaty tahun 1977. AHP merupakan pendekatan praktis dalam pengambilan keputusan yang efektif melalui penyajian 
hubungan hierarki antar faktor, atribut, karakeristik atau alternatif untuk memecahkan masalah kompleks (Bayuaji et al., 2016).

Nilai harkat daerah sulit air tanah di perbukitan Prambanan ditentukan dengan skor akhir dari akumulasi masing-masing parameter tertinggi dan terendah yang dibagi dalam empat harkat sesuai dengan parameter yang paling berpengaruh seperti terlihat pada Tabel 1 .

Tabel 1. Klasifikasi potensi dan tingkat sulit air tanah

\begin{tabular}{cll}
\hline Kelas & Interval & \multicolumn{1}{c}{ Kriteria } \\
\hline 4 & $>3,00$ & Potensi air tanah tinggi (sangat mudah air) \\
\hline 3 & $2,50-3,00$ & Potensi air tanah sedang (mudah air) \\
\hline 2 & $2,00-2,50$ & Potensi air tanah rendah (sulit air) \\
\hline 1 & $<2,00$ & Potensi air tanah sangat rendah (sangat sulit air) \\
\hline
\end{tabular}

Daerah dengan potensi air tanah tinggi merupakan daerah yang memiliki air tanah yang besar sepanjang tahun, termasuk pada daerah dengan satuan batuan yang permeable, bentuk lahan pada daerah ini sangat mendukung sebagai daerah tangkapan air, memiliki kedalaman muka air tanah dangkal, dan memiliki ketebalan tanah tebal sebagai media resapan yang baik. Ketersediaan air tanah pada daerah ini melimpah sepanjang tahun. Daerah dengan potensi air tanah tinggi termasuk daerah yang sangat mudah air.

Daerah dengan potensi air tanah sedang merupakan daerah yang memiliki air tanah yang cukup sepanjang tahun, termasuk dalam daerah dengan satuan batuan yang semi-permeable, bentuk lahan pada daerah ini mendukung sebagai daerah tangkapan air, memiliki kedalaman muka air tanah dangkal sampai sedang, dan memiliki ketebalan tanah sedang sampai tebal sebagai media resapan yang cukup. Daerah dengan potensi air tanah sedang termasuk daerah yang mudah air.

Daerah dengan potensi air tanah rendah merupakan daerah yang memiliki air tanah yang cukup pada musim penghujan dan terbatas pada musim kemarau, termasuk dalam daerah dengan satuan batuan yang semi-permeable, bentuk lahan pada daerah ini kurang mendukung sebagai daerah tangkapan air, memiliki kedalaman muka air tanah cenderung sedang sampai dalam, dan memiliki ketebalan tanah sedang sampai tipis sebagai media resapan yang kurang baik. Daerah dengan potensi air tanah rendah termasuk daerah yang sulit air.

Daerah dengan potensi air tanah sangat rendah merupakan daerah yang memiliki air tanah yang cukup sampai kurang pada musim penghujan dan sangat kurang pada musim kemarau, 
termasuk dalam daerah dengan satuan batuan yang semi-permeable - impermeable, bentuk lahan pada daerah ini tidak mendukung sebagai daerah tangkapan air, memiliki kedalaman muka air tanah cenderung dalam bahkan tidak terukur, dan memiliki ketebalan tanah sedang sampai tipis sebagai media resapan yang tidak baik. Daerah dengan potensi air tanah sangat rendah termasuk daerah yang sangat sulit air.

\section{HASIL DAN PEMBAHASAN}

\subsection{Hasil Pembobotan dengan Analitycal Hierarchy Process (AHP)}

Dalam penelitian ini, dilakukan skoring menggunakan pembobotan (weighting) dan pengharkatan (rating) melalui metode analitycal hierarchy process (AHP) untuk memetakan potensi air bawah tanah. Enam parameter yang digunakan yaitu bentuk lahan, ketebalan tanah, satuan batuan, kedalaman muka air tanah, tingkat pelapukan batuan, dan kerapatan bidang diskontinuitas. Hasil pembobotan dan pengharkatan dengan AHP yang telah disesuaikan dengan tingkat pengaruh dari masing masing parameter dapat dilihat pada Tabel 2. Sementara itu, klasifikasi potensi dan tingkat sulit air tanah untuk masing-masing parameter dapat dilihat pada Tabel 3.

Tabel 2. Parameter dan kriteria pemetaan potensi air bawah tanah dan hasil skoring

\begin{tabular}{|c|c|c|c|c|c|}
\hline Parameter & Sub-Parameter & Kategori & Harkat & Bobot & Skor \\
\hline \multirow{9}{*}{ Satuan batuan } & Batupasir & $\begin{array}{l}\text { Akuifer sangat } \\
\text { baik }\end{array}$ & 4 & \multirow{9}{*}{0,241} & 0,965 \\
\hline & Breksi dan Konglomerat & \multirow{2}{*}{ Akuifer baik } & \multirow{2}{*}{3} & & \multirow{2}{*}{0,724} \\
\hline & Batugamping Klastik & & & & \\
\hline & Batulanau & \multirow{3}{*}{ Akuifer buruk } & \multirow{3}{*}{2} & & \multirow{3}{*}{0,483} \\
\hline & Lapili & & & & \\
\hline & Batugamping Nonkalstik & & & & \\
\hline & Batuan Beku & \multirow{3}{*}{$\begin{array}{l}\text { Akuifer sangat } \\
\text { buruk }\end{array}$} & \multirow{3}{*}{1} & & \multirow{3}{*}{0,241} \\
\hline & Tuf & & & & \\
\hline & Batulempung & & & & \\
\hline \multirow{8}{*}{ Bentuk lahan } & Dataran & $\begin{array}{l}\text { Zona tangkapan } \\
\text { sangat baik }\end{array}$ & 4 & \multirow{8}{*}{0,138} & 0,553 \\
\hline & Dataran Bergelombang & Zona tangkapan & 3 & & \multirow{2}{*}{0,415} \\
\hline & Lembah & baik & 3 & & \\
\hline & Punggungan & \multirow{3}{*}{$\begin{array}{l}\text { Zona tangkapan } \\
\text { cukup }\end{array}$} & \multirow{3}{*}{2} & & \multirow{3}{*}{0,276} \\
\hline & Perbukitan & & & & \\
\hline & Bukit & & & & \\
\hline & Pegunungan & \multirow{2}{*}{$\begin{array}{l}\text { Zona tangkapan } \\
\text { buruk }\end{array}$} & \multirow{2}{*}{1} & & \multirow{2}{*}{0,138} \\
\hline & Lereng Terjal (Gawir) & & & & \\
\hline \multirow{4}{*}{$\begin{array}{l}\text { Kedalaman muka } \\
\text { air tanah } \\
\text { (meter) }\end{array}$} & $0-10,99$ & Dangkal & 4 & \multirow{4}{*}{0,110} & 0,441 \\
\hline & $11-14,99$ & Sedang & 3 & & 0,331 \\
\hline & $15-20$ & Dalam & 2 & & 0,220 \\
\hline & $>20$ & Sangat dalam & 1 & & 0,110 \\
\hline \multirow{4}{*}{$\begin{array}{l}\text { Ketebalan tanah } \\
\text { (meter) }\end{array}$} & $>3$ & Sangat tebal & 4 & \multirow{4}{*}{0,079} & 0,315 \\
\hline & $2-2,99$ & Tebal & 3 & & 0,237 \\
\hline & $1-1,99$ & Tipis & 2 & & 0,158 \\
\hline & $0-0,99$ & Sangat tipis & 1 & & 0,079 \\
\hline
\end{tabular}




\begin{tabular}{|c|c|c|c|c|c|}
\hline Parameter & Sub-Parameter & Kategori & Harkat & Bobot & Skor \\
\hline \multirow{4}{*}{$\begin{array}{l}\text { Tingkat pelapukan } \\
\text { batuan }\end{array}$} & Segar-Perubahan Warna Di Permukaan & Sangat Rendah & 4 & \multirow{4}{*}{0,216} & 0,863 \\
\hline & Terubah Warna Dan Fisik <25\% & Rendah & 3 & & 0,647 \\
\hline & Terubah Fisik 25-50\% & Sedang & 2 & & 0,431 \\
\hline & Terubah Fisik >50\% & Tinggi & 1 & & 0,216 \\
\hline \multirow{4}{*}{$\begin{array}{l}\text { Kerapatan bidang } \\
\text { diskontinuitas }\end{array}$} & Tidak Ada Kekar & Sangat Rendah & 4 & \multirow{4}{*}{0,216} & 0,863 \\
\hline & $1-3 /$ meter & Rendah & 3 & & 0,647 \\
\hline & $3-10 /$ meter & Sedang & 2 & & 0,431 \\
\hline & $>10 /$ meter & Tinggi & 1 & & 0,216 \\
\hline
\end{tabular}

Tabel 3. Klasifikasi dan kriteria potensi air bawah tanah serta daerah sulit air

\begin{tabular}{|c|c|c|c|c|c|c|c|}
\hline \multirow{2}{*}{$\begin{array}{l}\text { Klasifikasi } \\
\text { Potensi } \\
\text { Air tanah }\end{array}$} & \multicolumn{6}{|c|}{ Kriteria } & \multirow[t]{2}{*}{$\begin{array}{c}\text { Keterdapatan } \\
\text { Air tanah }\end{array}$} \\
\hline & $\begin{array}{l}\text { Bentuk } \\
\text { Lahan }\end{array}$ & $\begin{array}{c}\text { Ketebalan } \\
\text { Tanah }\end{array}$ & $\begin{array}{l}\text { Satuan } \\
\text { Batuan }\end{array}$ & $\begin{array}{c}\text { Kedalaman } \\
\text { Muka Air } \\
\text { tanah }\end{array}$ & $\begin{array}{c}\text { Tingkat } \\
\text { Pelapukan } \\
\text { Batuan }\end{array}$ & $\begin{array}{c}\text { Kerapatan } \\
\text { Bidang } \\
\text { Diskontinuitas } \\
\end{array}$ & \\
\hline Tinggi & $\begin{array}{l}\text { Dataran, } \\
\text { Lembah, } \\
\text { Dataran } \\
\text { Bergelombang }\end{array}$ & $\begin{array}{l}\text { Sangat } \\
\text { Tebal, } \\
\text { Tebal }\end{array}$ & $\begin{array}{l}\text { Batupasir, } \\
\text { Breksi, } \\
\text { Konglomerat } \\
\text { dan } \\
\text { Batugamping } \\
\text { Klastik, } \\
\text { Endapan } \\
\text { Pasir dan } \\
\text { Lebih Besar }\end{array}$ & $\begin{array}{l}\text { Dangkal } \\
\text { Dangkal- } \\
\text { Sedang }\end{array}$ & $\begin{array}{l}\text { Terubah } \\
\text { Fisik } \\
>50 \%\end{array}$ & $>10 /$ meter & $\begin{array}{c}\text { Sangat Mudah } \\
\text { Air }\end{array}$ \\
\hline Sedang & $\begin{array}{l}\text { Dataran } \\
\text { Bergelombang, } \\
\text { Lembah, } \\
\text { Punggungan } \\
\text { Perbukitan } \\
\text { Bukit }\end{array}$ & Tebal & $\begin{array}{l}\text { Breksi, } \\
\text { Konglomerat, } \\
\text { Batugamping } \\
\text { Klastik }\end{array}$ & $\begin{array}{l}\text { Sedang } \\
\text { Sedang- } \\
\text { Dalam }\end{array}$ & $\begin{array}{l}\text { Terubah } \\
\text { Fisik 25- } \\
50 \% \text {, } \\
\text { Terubah } \\
\text { Fisik } \\
>50 \%\end{array}$ & $\begin{array}{l}\text { 3-10/meter, } \\
>10 / \text { meter }\end{array}$ & Mudah Air \\
\hline Rendah & $\begin{array}{l}\text { Punggungan } \\
\text { Perbukitan } \\
\text { Bukit }\end{array}$ & Tipis & $\begin{array}{l}\text { Batulanau, } \\
\text { Lapili, } \\
\text { Batugamping } \\
\text { Nonklastik, } \\
\text { Endapan } \\
\text { Lempung }\end{array}$ & Dalam & $\begin{array}{l}\text { Terubah } \\
\text { Warna } \\
\text { Dan Fisik } \\
<25 \%, \\
\text { Terubah } \\
\text { Fisik 25- } \\
50 \%\end{array}$ & $\begin{array}{l}\text { 1-3/meter } \\
3-10 / \text { meter }\end{array}$ & Sulit Air \\
\hline $\begin{array}{l}\text { Sangat } \\
\text { Rendah }\end{array}$ & $\begin{array}{l}\text { Pegunungan } \\
\text { Lereng Terjal }\end{array}$ & $\begin{array}{l}\text { Sangat } \\
\text { Tipis }\end{array}$ & $\begin{array}{l}\text { Batuan Beku } \\
\text { Tuff } \\
\text { Batulempung }\end{array}$ & $\begin{array}{l}\text { Sangat } \\
\text { Dalam }\end{array}$ & $\begin{array}{l}\text { Segar- } \\
\text { Perubahan } \\
\text { Warna Di } \\
\text { Permukaan }\end{array}$ & $\begin{array}{l}\text { Tidak Ada } \\
\text { Kekar }\end{array}$ & $\begin{array}{c}\text { Sangat Sulit } \\
\text { Air }\end{array}$ \\
\hline
\end{tabular}

\subsection{Hasil Pemetaan dan Pengamatan Lapangan}

Penelitian sebaran daerah sulit air tanah perbukitan Prambanan, Sleman, Daerah Istimewa Yogyakarta dilakukan dengan pemetaan dan pengamatan lapangan untuk memperoleh data serta informasi yang diperlukan sesuai dengan enam parameter sebaran daerah sulit air tanah dengan lokasi pengamatan yang disesuaikan dengan kebutuhan seperti pada Gambar 2. 


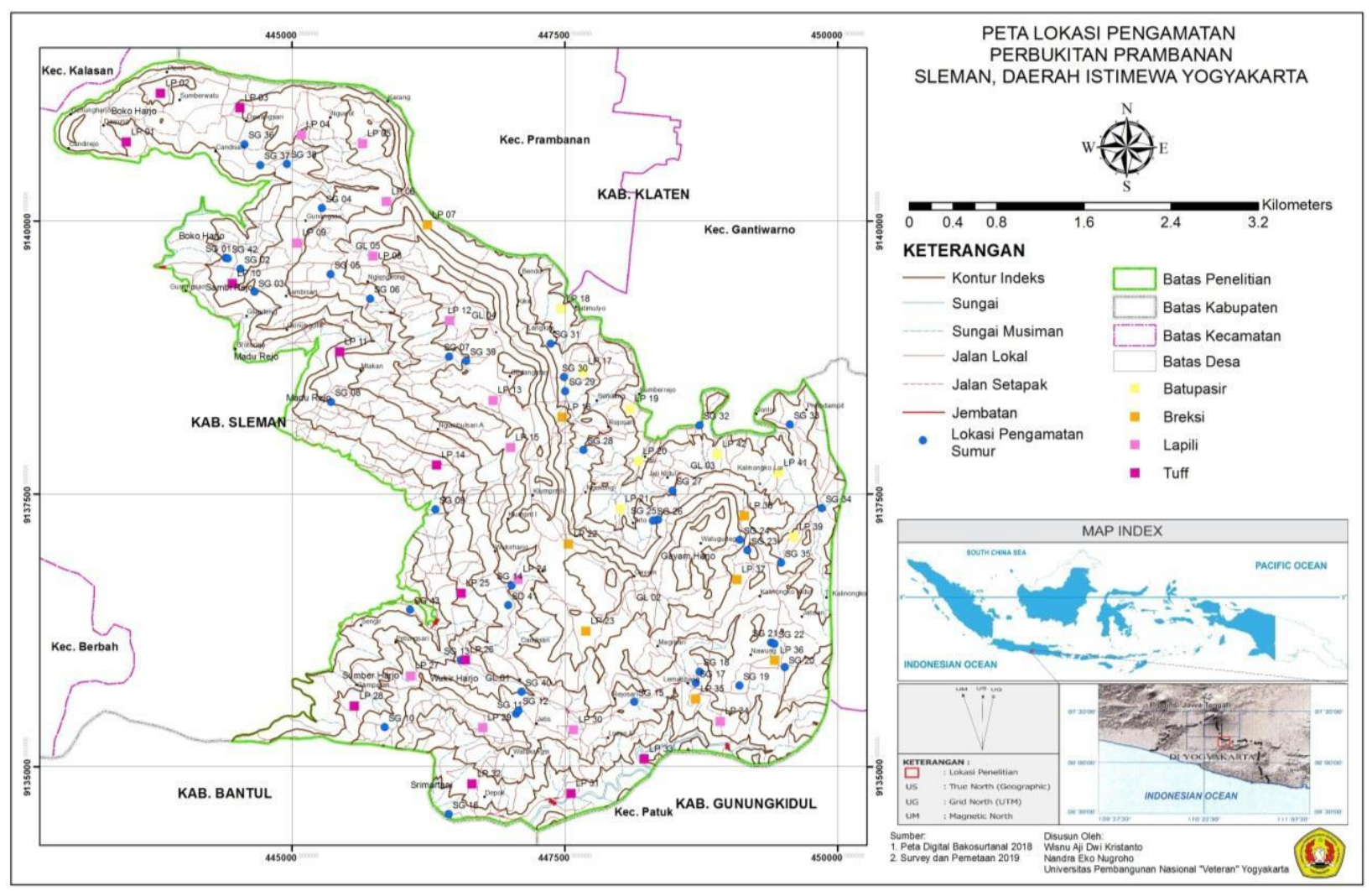

Gambar 2. Peta lokasi pengamatan daerah perbukitan Prambanan

\subsubsection{Satuan Batuan}

Hasil pemetaan dan analisis batuan pada lokasi penelitian terdapat empat satuan batuan yang mendominasi yaitu satuan tuff, satuan lapilli, satuan breksi, dan satuan batupasir tuffan (Gambar 3). Kondisi sebaran batuan yang ada relatif mengikuti bentuk lahan yang ada dan pola kerapatan kontur. Kondisi batuan merupakan faktor yang berpengaruh terdapat keterdapatan air tanah karena merupakan wadah atau tempat simpanan air tanah.

\subsubsection{Bentuk Lahan}

Hasil analisis peta topografi daerah penelitian terdapat empat satuan bentuk lahan yaitu lembah, perbukitan, punggungan, dan lereng terjal (Gambar 4). Bentuk lahan digunakan karena berhubungan dengan air limpasan permukaan (runoff) yang diasumsikan bahwa daerah dengan bentuk lahan dengan kelerengan terjal akan mudah menghasilkan runoff daripada daerah dengan bentuk lahan dengan kelerengan landai 


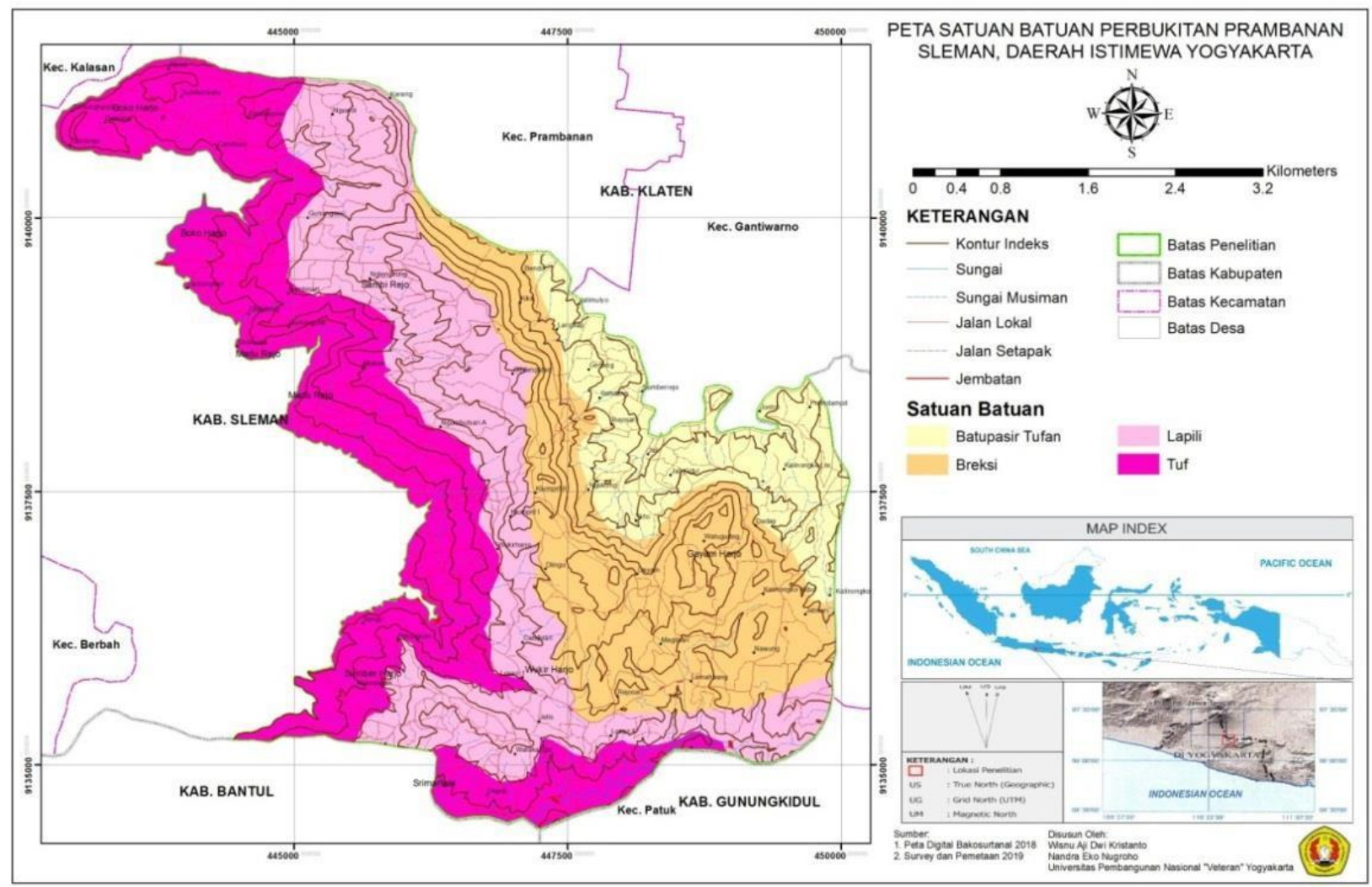

Gambar 3. Peta satuan batuan daerah perbukitan Prambanan.

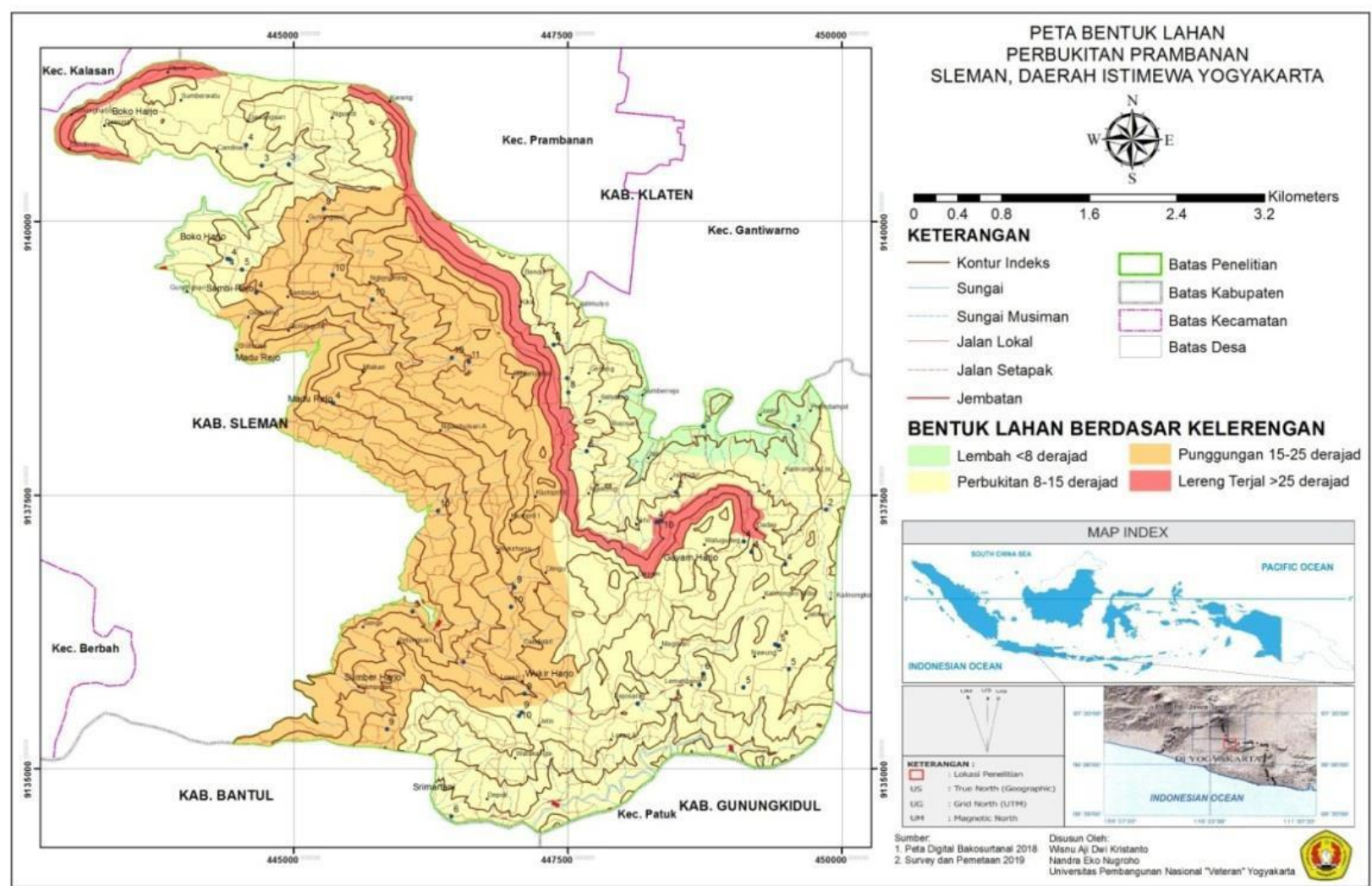

Gambar 4. Peta bentuk lahan daerah perbukitan Prambanan. 


\subsubsection{Kedalaman Muka Air tanah}

Hasil pemetaan kedalaman muka air tanah dilapangan dilakukan berdasarkan data sumur gali yang ada di daerah lokasi penelitian. Parameter kedalaman muka air tanah mewakili kemudahan pengambilan air tanah. Semakin dangkal muka air tanah, semakin mudah dan murah dalam eksploitasinya. Hasil pengamatan di lapangan terdapat tiga jenis kelompok kedalaman air tanah berdasarkan kelompok kemudahan eksploitasinya yaitu 0-3 meter, 3-10 meter, dan 10-15 meter (Gambar 5).

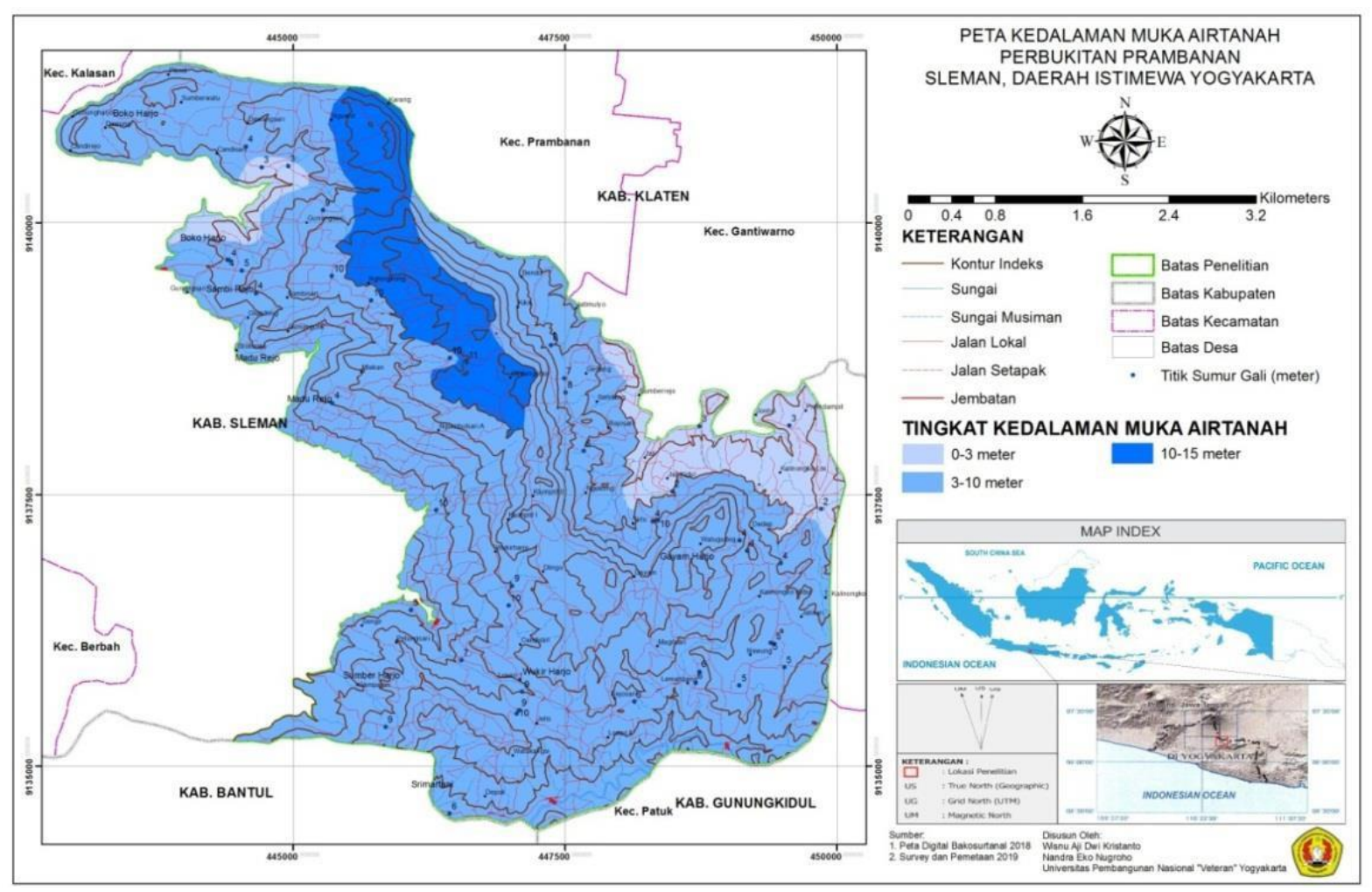

Gambar 5. Peta kedalaman muka air tanah daerah perbukitan Prambanan.

\subsubsection{Ketebalan Tanah}

Hasil survei lapangan tingkat ketebalan tanah di lokasi penelitian terbagi atas tiga zona ketebalan yaitu zona sangat tipis $(<1 \mathrm{~m})$, tipis $(1-2 \mathrm{~m})$, dan tebal $(>2 \mathrm{~m})$ (Gambar 6). Parameter ketebalan tanah merupakan media resapan awal air permukaan. Semakin tebal tanah akan semakin banyak air yang terinfiltrasi kebawah permukaan. Ketebalan tanah dipengaruhi salah satunya adalah bentuk lahan sekaligus kemiringan lereng yang ada. Kemiringan lereng yang semakin tinggi akan membuat proses pembentukan tanah semakin lama akibat air lebih berpotensi menjadi runoff sehingga infiltrasi berkurang dan proses pelapukan batuan menjadi lebih lama yang berdampak pada ketebalan tanah yang tipis. 


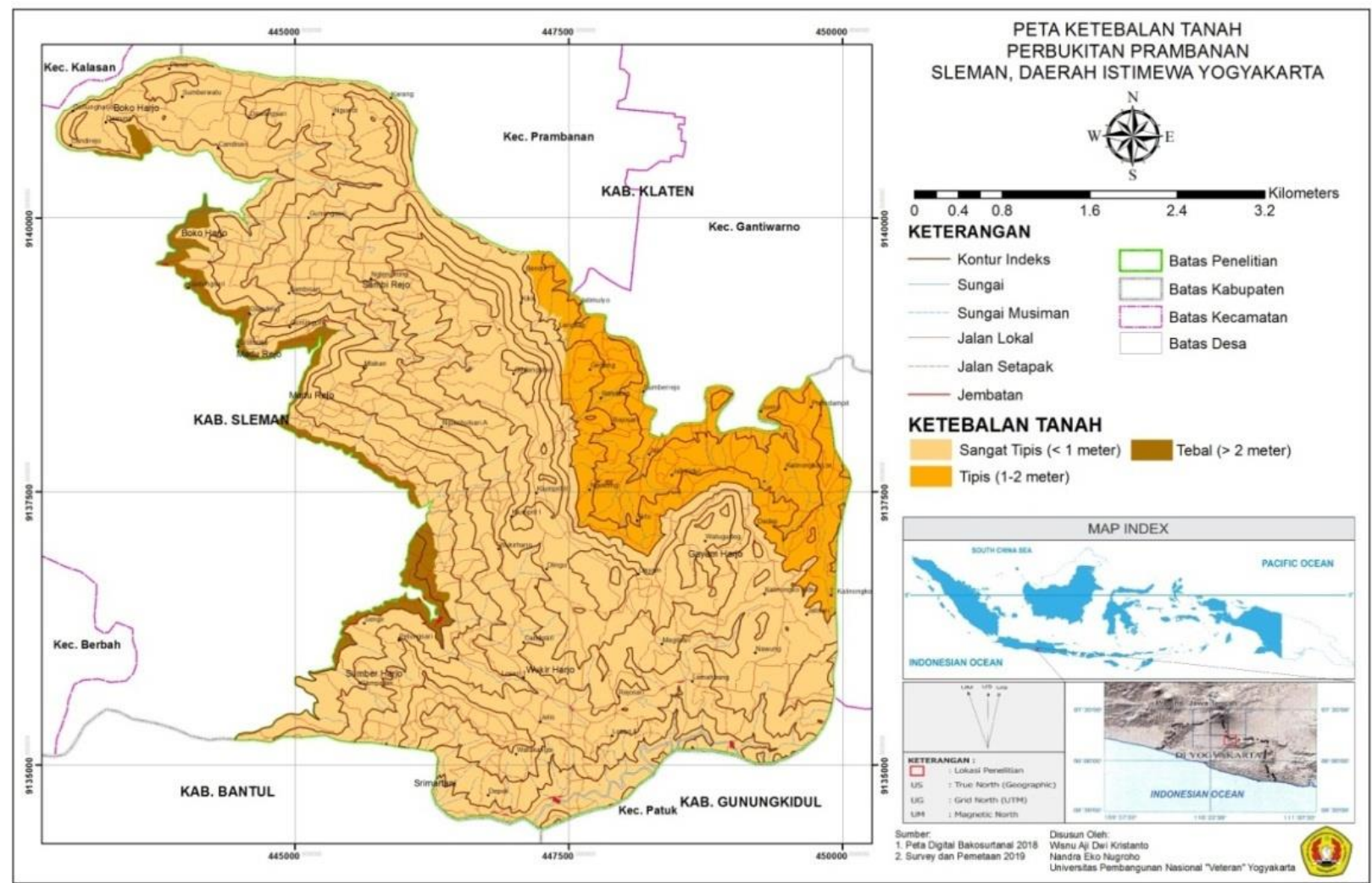

Gambar 6. Peta ketebalan tanah daerah perbukitan Prambanan.

\subsubsection{Tingkat Pelapukan Batuan}

Hasil analisis tingkat pelapukan batuan pada lokasi penelitian terdapat tiga tingkat pelapukan batuan yaitu tingkat pelapukan rendah, sedang, dan tinggi (Gambar 7). Tingkat pelapukan batuan memberikan gambaran tingkat kemampuan batuan untuk menampung dan mendistribusikan air melalui ruang antar butir yang berkembang seiring lapuknya batuan. Tingkat pelapukan yang tinggi ditandai dengan perubahan warna batuan yang semakin menjauh dari warna asli batuan.

\subsubsection{Kerapatan Bidang Diskontinuitas}

Hasil pengamatan dan analisis pada lokasi penelitian terbagi atas tiga kerapatan bidang diskontinuitas (Gambar 8). Bidang diskontinuitas terkait dengan kehadiran kekar maupun bidang lainnya seperti: bidang perlapisan, zona lapukan batuan, struktur geologi dan bidang yang memutus tubuh batuan lainnya. Semakin rapat bidang diskontinuitas akan lebih memudahkan air terakumulasi pada ruang bidang tersebut yang dapat berkembang sebagai akuifer sekunder. 


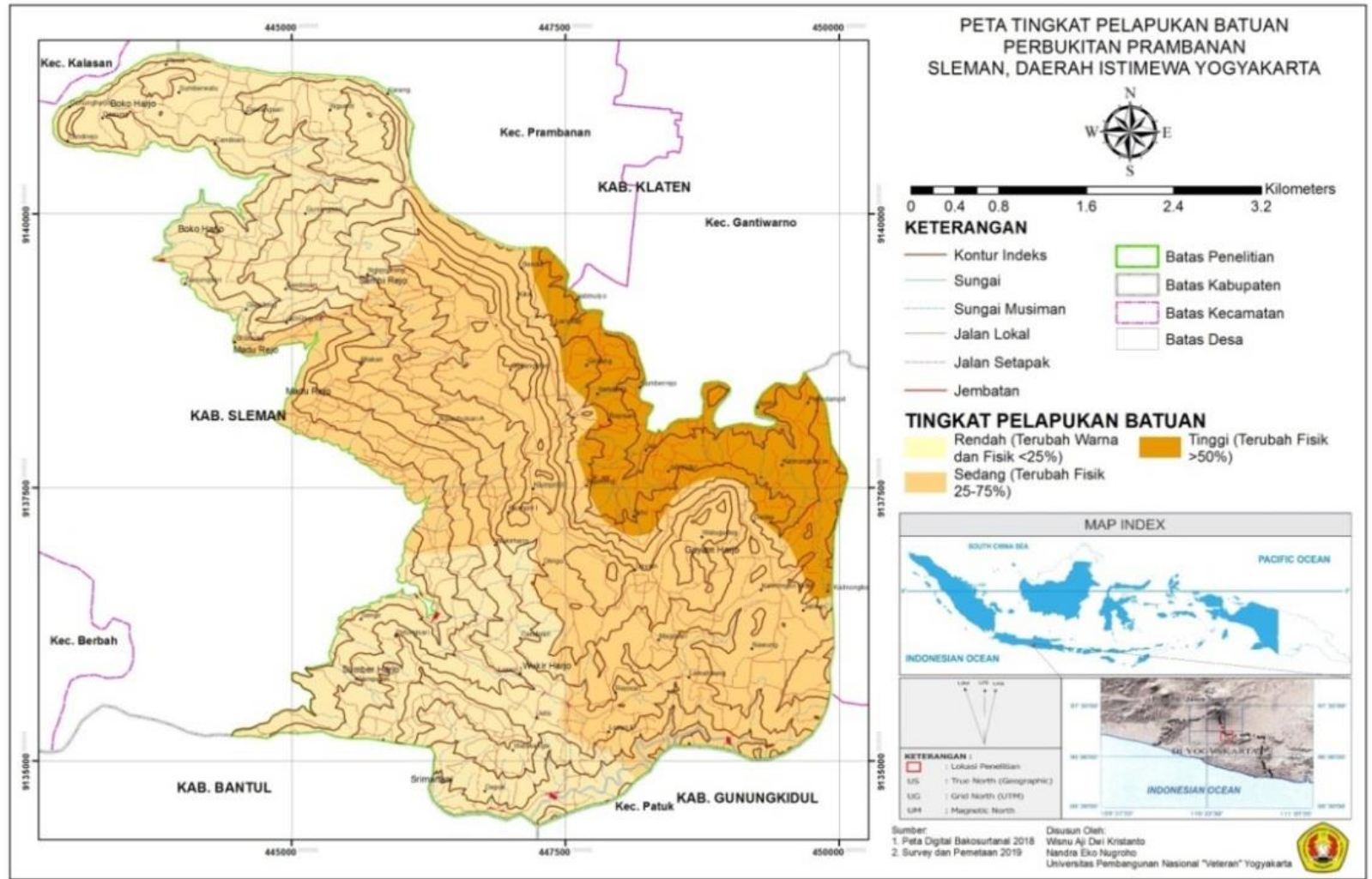

Gambar 7. Peta tingkat pelapukan daerah perbukitan Prambanan.

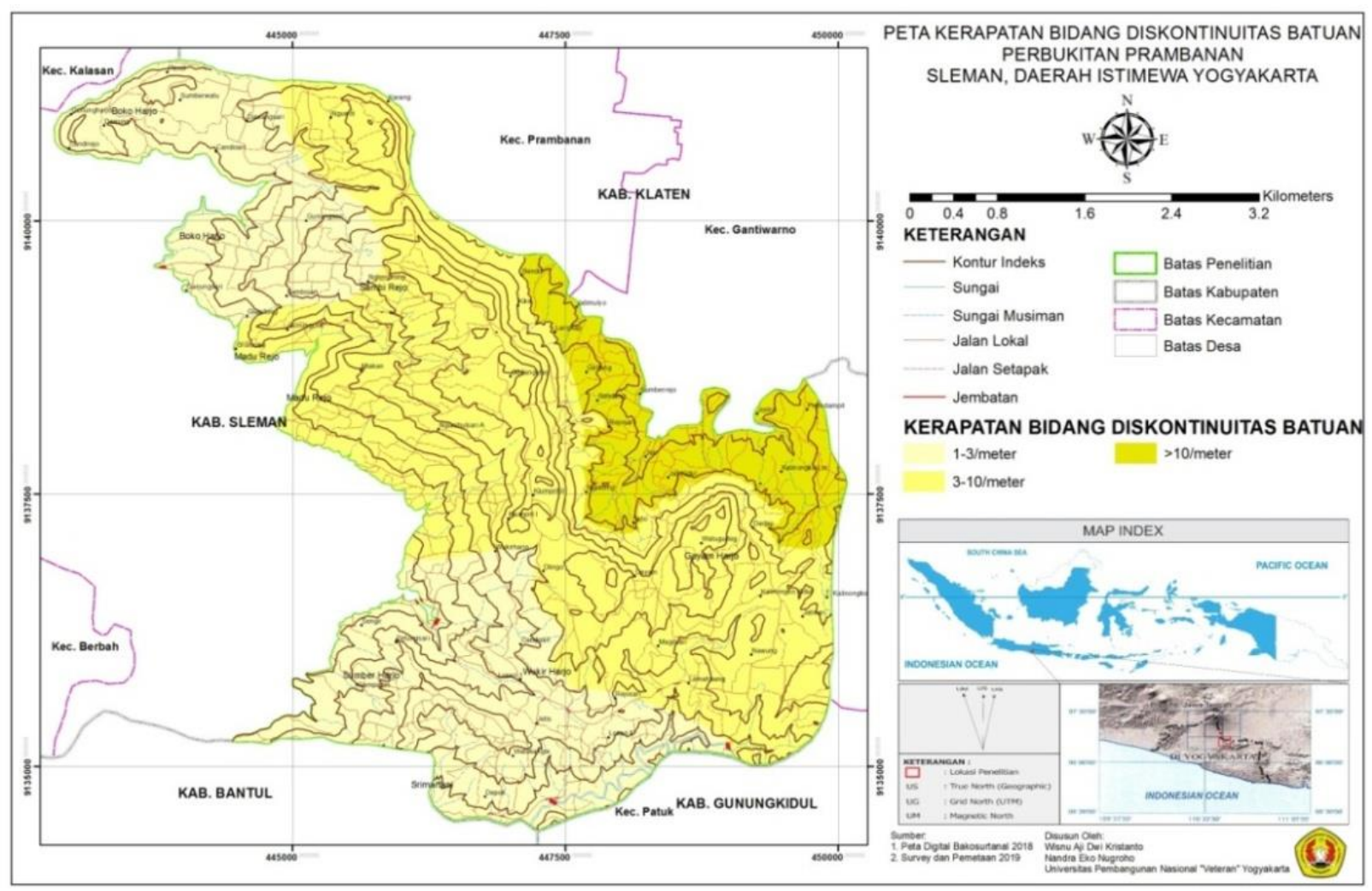

Gambar 8. Peta kerapatan bidang diskontinuitas daerah perbukitan Prambanan. 


\subsection{Peta Sebaran Daerah Sulit Air tanah}

Hasil analisis pembobotan dari parameter satuan batuan, bentuk lahan, ketebalan tanah, kedalaman muka air tanah, tingkat pelapukan batuan, dan kerapatan bidang diskontiunitas. menghasilkan beberapa tingkat sulit air tanah yang ada di perbukitan Prambanan (Gambar 9). Zona yang dihasilkan terbagi menjadi empat yaitu sangat sulit, sulit, mudah, dan sangat mudah. Sebagai salah satu contoh daerah sangat sulit air tanah memiliki bentuk lahan punggunganlereng terjal, ketebalan tanah sangat tipis, satuan batuan lapili dan tuf, kedalaman muka air tanah dalam, tingkat pelapukan batuan rendah, dan kerapatan batuan rendah. Karakter ini menjadikan daerah tersebut memiliki potensi air tanah yang sangat rendah. Untuk panduan membaca keseluruhan sebaran sulit air tanah dapat dilihat di tabel 3 dengan memperhatikan nilai akumulasi pada tabel 1 .

Secara deskriptif pembagian zona sebaran sulit air tanah daerah perbukitan Prambanan adalah sebagai berikut:

1. Zona sangat sulit air tanah merupakan zona yang mendominasi sekitar luasan $45 \%$ daerah penelitian dengan sebaran dari arah utara melintang seacara sempit ke arah selatan. Zona ini sangat dipengaruhi oleh susunan batuan mengingat bahwa air tanah tersimpan pada akuifer sehingga karakter batuan tuf dan lapili yang mempunyai karakter buruk sangat berpengaruh pada ketersediaan air bawah permukaan. Hal ini ditambah dengan tingkat pelapukan yang rendah dan sedang sehingga pada kedua faktor ini berakibat pada potensi air bawah permukaan yang sangat rendah.

2. Zona sulit air tanah memiliki luasan $25 \%$ daerah penelitian dengan sebaran sempit dari arah utara melintang seacara meluas ke arah selatan. Karakteristik pada zona ini adalah pengaruhi oleh tingkat pelapukan yang rendah sampai sedang dan bidang diskontinuitas yang dengan kerapatan 3-10 bidang/meter serta bentuk lahan yang berupa perbukitan dan punggungan namun karena satuan batuan adalah breksi yang mempunyai karakter baik sebagai akufer sehingga pada daerah ini mempunyai potensi air bawah permukaan yang rendah.

3. Zona mudah air tanah memiliki luasan 5\% daerah penelitian dengan sebaran secara spotspot pada sisi barat dengan luasan kecil. Zona potensi mempunyai karakteristik terdapat pada satuan satuan tuf dan lapili, tingkat pelapukan yang rendah sampai sedang dan bidang diskontinuitas yang dengan kerapatan 3-10 bidang/meter. Namun dengan adanya bentuk lahan berupa lembah, kedalaman air tanah yang dangkal dan ketebalan tanah yang cukup tebal membuat daerah ini mempunyai potensi air bawah permukaan yang sedang. 
4. Zona sangat mudah air tanah memiliki luasan $15 \%$ daerah penelitian dengan sebaran secara spot-spot pada sisi barat dengan luasan kecil dan luasan yang cukup besar pada sisi bagian timur. Zona potensi air bawah permukaan tinggi ini mempunyai karakteristik terdapat pada satuan satuan batupasir tufan serta lapili dan tuf dengan luasan kecil, tingkat pelapukan yang tinggi sampai sedang bidang diskontinuitas yang dengan kerapatan >10 bidang/meter, bentuk lahan lembah, dan kedalaman air tanah yang dangkal (0-3m). Parameter yang berpengaruh tersebut mempunyai dampak postif terhadap potesi air bawah permukaan sehingga membuat daerah ini mempunyai potensi air bawah permukaan yang tinggi.

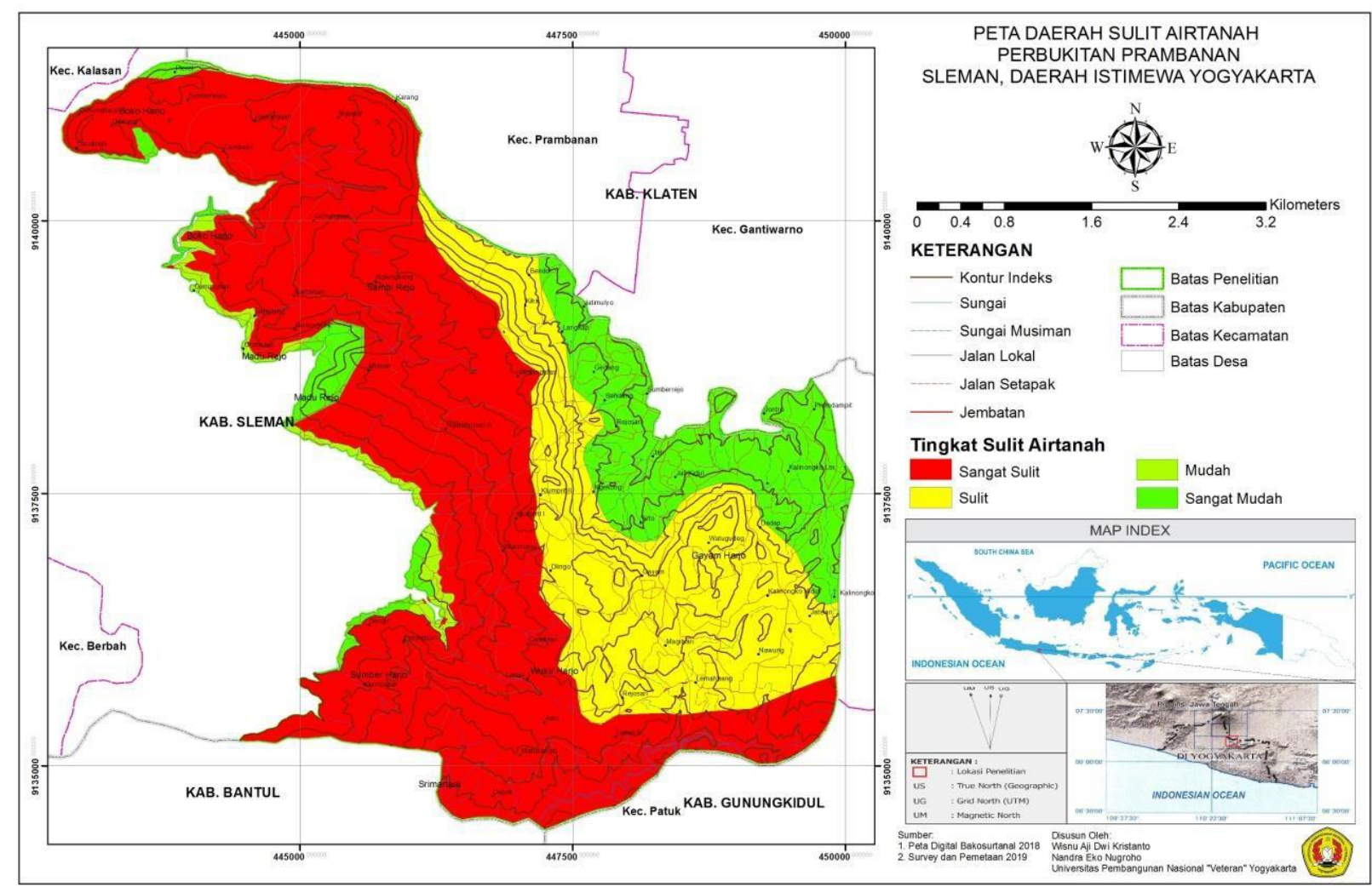

Gambar 9. Peta sebaran daerah sulit air tanah daerah perbukitan Prambanan.

\section{KESIMPULAN}

Hasil analisis pembobotan dari parameter satuan batuan, bentuk lahan, ketebalan tanah, kedalaman muka air tanah, tingkat pelapukan batuan, dan kerapatan bidang diskontiunitas menghasilkan beberapa tingkat sulit air tanah yang ada di perbukitan Prambanan. Zona yang dihasilkan terbagi menjadi empat yaitu sangat sulit, sulit, mudah, dan sangat mudah. Metode penelitian ini dapat diterapkan di daerah penelitian yang lain sebagai dasar perencanaan kebutuhan air masyarakat. 
Daerah perbukitan Prambanan memiliki zona sulit air yang lebih luas daripada yang mudah air. Untuk mengatasi ini, penulis memberikan beberapa saran yaitu: membangun bangunan embung di daerah bukit dengan memperhatikan optimalisasi tangkapan air dan mengoptimalkan sumber air dari daerah dataran kaki perbukitan dengan distribusi pipa. Semua ini dapat dilakukan dengan penelitian lebih lanjut.

\section{DAFTAR PUSTAKA}

Aryanto, D.E dan Hardiman, G. (2017). Kajian Multi Varian Faktor yang Berpengaruh terhadap Infiltrasi Air Tanah sebagai Dasar Penentuan Daerah Potensial Resapan Air Tanah. Proceeding Biology Education conference, 14 (1) : 252-257.

Badan Nasional Penanggulangan Bencana. (2010). Peta Kejadian Bencana Kekeringan di Indonesia Tahun 1979-2009. Badan Nasional Penanggulangan Bencana. Jakarta.

Bayuaji, D.G., Nugraha, A.L dan Sukmono, A. (2016). Analisis Penentuan Zonasi Risiko Bencana Tanah Longsor Berbasis Sistem Informasi Geografis (Studi Kasus : Kabupaten Banjarnegara). Jurnal Geodesi Undip, 5 (1) : 326-335.

Dinas Pekerjaan Umum, Perumahan dan Energi Sumber Daya Mineral Daerah Istimewa Yogyakarta. (2018). Identifikasi Daerah Sulit Air di Kabupaten Sleman dan Bantul.

Dinas Pekerjaan Umum, Perumahan dan Energi Sumber Daya Mineral Daerah Istimewa Yogyakarta. (2011). Rencana Program Kegiatan Pengelolaan Air Tanah di Cekungan Air Tanah Yogyakarta-Sleman.

Dinas Pekerjaan Umum, Perumahan dan Energi Sumber Daya Mineral Daerah Istimewa Yogyakarta. (2011). Pemetaan Zonasi Konservasi Air Tanah di Cekungan Air Tanah Yogyakarta-Sleman.

Hadihardaja J. (1997). Irigasi dan Bangunan Air. Kopertis. Jakarta.

Jone, Y. (2018). Kajian Potensi Air Tanah Dan Pembagian Wilayah Potensi di Cekungan Air

Tanah Maumere. Jurnal IPTEK, 22(1): 21-27.

Komaruddin. (2000). Kamus Istilah Karya Ilmiah. Bumi Aksara. Jakarta.

Kristanto W.A.D., Indrawan I.G.B. (2018). Karakteristik Geologi Teknik Daerah Prambanan

Dan Sekitarnya, Kecamatan Prambanan, Kabupaten Sleman, Daerah Istimewa Yogyakarta. Jurnal KURVATEK, 3(2): 21-29.

Prayogo, T. (2014). Kajian Kondisi Air Tanah Dangkal Daerah Wonomarto, Lampung Utara. Jurnal Teknologi Lingkungan, 15(2): 107-114. 
Rahardjo, Wartono, Sukandarrumidi, Rosidi H.M.D. (1995). Peta Geologi Lembar Yogyakarta, Jawa, Skala 1:100.000. Pusat Penelitian dan Pengembangan Geologi. Bandung.

Riastika, M. (2012). Pengelolaan Air Tanah Berbasis Konservasi Di Recharge Area Boyolali (Studi Kasus Recharge Area Cepogo, Boyolali, Jawa Tengah). Jurnal Ilmu Lingkungan, 9(2) : 86-97.

Saaty T.L. (1977). A Scaling Method for Priorities in Hierarchical Structures. Journal of Mathematical Psychology; Vol. 15: 234-281.

Santosa L.W., Adji T.N. (2018). Karakteristik Akuifer dan Potensi Air tanah Graben Bantul. UGM PRESS. Yogyakarta.

Sudjab, B.A., As'ari dan Tanauma, A. (2012). Pemetaan Akuifer Air Tanah Di Sekitar Candi Prambanan Kabupaten Sleman Daerah Istimewa Yogyakarta Dengan Menggunakan Metode Geolistrik Tahanan Jenis. Jurnal MIPA Unsrat Online, 1(1) : 27-44.

Sulu, S.S, As'ari dan Tongkukut, S.H.J. (2015), Pemetaan Akifer Air Tanah di Wilayah Kampus Unstrat Manado dengan Menggunakan Metode Geolistrik Tahanan. Jurnal Ilmiah Sains, 15 (1) : 20 - 26.

Sunarwan, B., Kamal, N dan Luthfi, M. (2015). Identifikasi Parameter Fisika Dan Kimia Airtanah Pada Akifer Endapan Produk Gunung Api (Studi Kasus : Cekungan Airtanah Bandung). Jurnal Teknologi, 2 (26) : 53-68.

Zeffitni. (2011). Identifikasi Batas Lateral Cekungan Airtanah (CAT) Palu. Jurnal SMARTek, 9(4): $337-349$. 